\title{
Analysis of Problems Existing in Rural Financial Products and Services Innovation in Henan Province
}

\author{
Ming-Gui CAO \\ College of Tourism, Xinyang Normal University \\ Xinyang, China \\ cmg68@163.com
}

\author{
Juan-Juan LI* \\ College of Business, Xinyang Normal University \\ Xinyang, China \\ $835925861 @ q q . c o m$
}

\begin{abstract}
Rural finance is the core of the modern rural economy. At present, the rural financial innovation in Henan province has obtained great achievements, financial innovation products emerge in endlessly, the mode of financial services is constantly being optimized. But there are still problems in rural financial reform and innovation, the initiative of financial innovation is not enough and obviously dependent on the government, the innovation subject is unitary and lacks innovation motive force, the level of innovation is low, the promotion and application is limited. Further analysis shows that the following conditions are restricting the reform and innovation of rural finance: the weak foundation condition of rural areas, the single financial structure and backward financial market, backward business concept and unbalanced loans on credit, adverse assessment mechanisms and inadequate policies, the lack of rural financial talents and technical support.
\end{abstract}

Keywords-Henan province; Rural areas; Financial roducts and ervices; Financial innovation

\section{INTRODUCTION}

Solving the problem of "agriculture, rural areas and farmers" has always been the most important task of the party and government. As is known to all, the financial development level has become an important indicator to measure the level of economic development of a country. Then, as the foundation of national economic construction, the rural economy is inseparable from the support of rural finance. In recent years, the momentum of rural financial development in our province is rising. By the end of 2016, the financial service has covered 1848 villages and towns, the coverage of administrative villages has reached up to $92.23 \%$ [1]. But in terms of the actual economic development of rural areas, rural financial reform and innovation is also facing many obstacles. On one hand, the population of Henan province is large, the slow urbanization process makes the rural population still remain a lot. By the end of 2016, the rural population accounted for $51.5 \%$ [2]. Rural weak characteristics make the rural financial reform and innovation difficult. On the other hand, rural financial innovation is still inadequate, neither the product type nor the service mode can meet the needs of the rural economic development. It is of great realistic value to analyse and study the products and services of rural finance in Henan province for the construction of a wide, high-level and sustainable rural financial system.

\section{The CURRENT SituAtion OF RURAL FinANCIAL PRODUCTS AND SERVICES INNOVATION IN HENAN PROVINCE}

\section{A. Rural Financial Innovation Products Emerge in Endlessly}

As far as the rural financial development is concerned, the financial product innovation of Henan province mainly focuses on credit product innovation. As of June 2017, the amount of agricultural loans reached to 1.62 trillion yuan, compared with the beginning of the year, 119.8 billion was added, the credit scale reached a new high level [3]. These results have a direct relationship with the continuous innovation of credit products. The credit innovation is mainly reflected in four aspects. The first is the innovation of collateral. According to the principle of flexibility and local conditions, the province expands all kinds of effective chattel and real estate collateral, such as mortgage of live livestock and poultry, tea right mortgage, forest right mortgage, and so on. The Second is the innovation of guarantee mechanism. It can solve the loan problem of farmers and small micro enterprises by establishing a new guarantee mechanism. For example, the business of leading enterprises + farmers + credit, it is a way of combining industry and finance, which can not only solve the guarantee problem but also guard against the risk. The third is credit enhancement innovation. The core of this innovation is joint-liability loan, multiple households are in joint guarantee or small micro businesses make loans together. The fourth is to set up specialized credit products. The loan, mainly for rural special labors, has been piloted in some areas.

The innovation of rural financial products is not unique, we are still trying new things in more ways. However, in terms of the real rural finance work in Henan province, the relatively fast and widely applicable financial innovation products have the following 10 categories. (As shown in the table 1)

Fund Project: The Major Application Research Project of Philosophy and Social Sciences of Henan

(No: 2017-YYZD-17), the Planning Project of Philosophy and Social Sciences of Henan

(No: 2016BJJ048)

The Author: Ming-Gui CAO (1964- ), male, born in Huangchuan, Henan province, professor, postgraduate tutor, the research focuses on regional economy. 


\begin{tabular}{|c|c|}
\hline Innovation product name & The specific content \\
\hline $\begin{array}{l}\text { stat-up loans of returning } \\
\text { home }\end{array}$ & $\begin{array}{l}\text { special loans designed for returned entrepreneurs and } \\
\text { enterprises }\end{array}$ \\
\hline $\begin{array}{l}\text { company + rural } \\
\text { professional cooperation } \\
\text { organization + farmers } \\
\text { small loans }\end{array}$ & $\begin{array}{l}\text { using multiple guarantee "company guarantee" + "rural } \\
\text { professional cooperative group guarantee" to meet the } \\
\text { needs of farmers' loan funds }\end{array}$ \\
\hline business pledge loans & $\begin{array}{c}\text { as a loan pledge, the enterprise management right is } \\
\text { handled by the loan party, and the loan party can provide } \\
\text { loan support in a timely manner }\end{array}$ \\
\hline order pledge loans & $\begin{array}{l}\text { taking the right to purchase and selling tea as a pledge, we } \\
\text { will make loans to tea farmers, large growers and } \\
\text { manufacturers of production \& processing }\end{array}$ \\
\hline $\begin{array}{l}\text { leading enterprises }+ \\
\text { farmers }+ \text { credit }\end{array}$ & $\begin{array}{l}\text { the joint development of financial institutions and leading } \\
\text { enterprises of agricultural industrialization, solving the } \\
\text { problem of effective mortgage guarantee for farmers }\end{array}$ \\
\hline
\end{tabular}

foreign labor export loans

corporate co-insurance loans

Forestry mortgage loans

chattel mortgage loans

two mortgage loans the aim is to provide loans for migrant workers

the county small and medium-sized enterprises to obtain the financing amount

taking forestry warrants as effective collateral to obtain loans

mortgage loans such as stocks owned by an enterprise

taking the rural land contract management right and farmer housing property right as the mortgage
Innovative features

the mortgage guarantee form is

diversified, the funds is in place fast, and

the loan interest rate is increased appropriately relying on agricultural professional organizations and enterprises, reducing the demand of farmers' mortgage guarantee, controlling the risk

the credit cycle is used, the loan procedures are simple, the cost is low, and the term of loan is relaxed

the loan term is reasonable, the amount is suitable, and the interest rate is flexible

credit costs and risks have been effectively reduced, reaching the multiwins of institutions, businesses and farmers

the amount is generally 3-5, the highest 100 thousand, The loan procedures are simple and the migrant workers are satisfied

promoting exchanges and cooperation between enterprises

the procedure is simple, the amount is high, the small amount is up to 5 million

expanding the scope of enterprise collateral

expending the effective collateral of farmers

\section{B. The Mode of Rural Financial Services Is Constantly Being Optimized}

With the rapid development of new technologies, the Internet, cloud computing and large data processing technology provide convenient and efficient financial services to the countryside. The issuance of bank cards and the application of automatic deposit machine solve the problem that farmers queue up to withdraw cash from the counter. Many banks in Henan rural areas have made full use of Internet platform to promote their own apps to farmers, so that the business of checking balance, transferring money, remittance can be operated at home. At the same time, the "two stations" (financial service station, community service station) and "two points" (convenience service point, support service point) have been set up in rural areas to provide farmers with a package of financial services which include medical insurance, pension insurance, in this way farmers can be able to achieve one-stop service without going out of their villages. In addition, rural credit cooperatives and $\mathrm{CMCC}$ have also began to catch up with the upsurge of "sharing economy", they signed a strategic cooperation agreement on August 28th 2017, decided to create the financial communicating service station. It means that farmers can transact mobile business in rural credit 
cooperatives and can also withdraw money from mobile business hall. As the core of rural financial system, the position of rural credit cooperatives is unshakable. Similarly, the weight of CMCC in the communication industry cannot be denied. Therefore, the combination of powerful enterprises will surely provide more comprehensive financial services for farmers, improve and optimize the service mode of rural finance in Henan province.

\section{PROBLEMS EXISTING IN THE INNOVATION OF RURAL FINANCIAL PRODUCTS AND SERVICES IN HENAN PROVINCE}

\section{A. The Initiative of Financial Innovation Is Not Enough and Obviously Dependent on the Government}

As a pilot province for rural financial products and services innovation, Henan province in 2009 established 18 counties as pilot units to launch financial innovation. The central government has always attached great importance to rural construction work, since 2004, No1 Central Document has been focused on "agriculture, rural areas and farmers" for 13 years, the 2017 central document once again pointed out to speed up rural financial innovation, strengthen the service of agriculture, rural areas and farmers. The government of Henan province on the problem of financial innovation is not idle, it issues "Implementation Plan of Promoting Rural Financial Reform Pilot Area of Central Plains Economic Zone in Henan province (2015 - 2020) ", the plan calls for efforts to raise the level of financial services for agriculture, rural areas and farmers, and indeed guarantee the coordinated development. In May 2017 the government organized a financial meeting in Zhengzhou, studying and implementing the spirit of General Secretary $\mathrm{Xi}$ Jinping's speech on financial innovation, exploring the financial development and security issues of the province under the new situation, emphasizing the deepened reform to strengthen financial innovation, promoting the development of farmers and small micro businesses. Thus, the financial innovation has obvious characteristics of administrative promotion, which relies heavily on the government. Administrative promotion is mandatory, effective and public, it can really accelerate the development of rural financial innovation in a short time, but whether the innovation under the government's control has a durable vitality is to be tested.

\section{B. The Innovation Subject Is Unitary and Lacks Innovation Motive Force}

The rural financial system of Henan province is dominated by non-commercial, commercial, cooperative formal financial institutions, and RCC is the core, some other informal financial institutions are supplemented. As the only policy bank in rural financial system, the agricultural development bank focuses on loans for purchasing grain, cotton and oil, providing financing services for leading agricultural enterprises, the service is narrow and lacks specialized services to farmers. The four major commercial banks have fewer branches in Henan rural areas, the agricultural banks are more common. But in recent years, agricultural banks driven by interests have begun to shift their positions to cities, those branches stayed in the countryside mainly serve the leading enterprises. The postal savings bank branches spread the villages and towns, but for a long time, the characteristic of "only save not loan" makes it become the rural economic "blood drawing machine", completely distorts the original nature. There is no real innovation in its credit business with the loan of low quality and less kinds recently. As a commercial financial organization, the village bank has been developing vigorously since the establishment of the first village bank in 2008. According to the statistical data, village banks have lent 167.1 billion yuan to 199.8 thousand households and small micro businesses over the past ten years [4].The development of village banks has effectively activated the rural financial market and injected fresh blood into the rural economy. However, considering the characteristics of its own pursuit of security and benefits, the loan is generally small, scattered, not what farmers want. The rural credit cooperatives is born in rural areas, and grows up in rural areas, the annual amount of agricultural loans accounted for $90 \%$ of the province, so the subject of rural financial innovation actually falls into rural credit cooperatives. Although the rural credit cooperatives occupies an absolute advantage in rural financial market, its own rectification still faces many problems ,such as inaccurate market positioning, poor management, poor governance, which makes it has no time to spare for the innovation work and lacks motivate force.

\section{The Level of Innovation Is Low, the Promotion and Application Is Limited}

Henan province has carried out a series of attempts on rural financial reform and innovation, the government and banks jointly launched more than 20 types of innovative financial products and promoted the intelligent development of financial services. Overall, rural financial innovation has achieved good results, the amount of innovative loans related to agriculture is as high as 10 billion, farmers' satisfaction with financial services continues to increase. However, if you carefully analyze the existing innovation results, you will find that the innovation level is low, the promotion and application of innovation results is limited. In terms of financial product innovation, the form is too simple. Tangible financial products include savings, insurance, financial management, remittances and so on, but the current rural financial product innovation is rarely involved in other areas, it is still limited to the credit business. Paying too much attention to the formal innovation is also a manifestation of low level. For example, the "stat-up loans of returning home" and "foreign labor export loans" that Henan has launched, it is just simply divided according to the different work, there is no substantial difference from the ordinary small loans, and no significant effect on ensuring the financial support for the laborers. In addition, the lack of promotion and application of financial innovation results is also a hindrance to financial reform. On one hand, financial innovation results have not been widely promoted, which resulted in uneven regional benefits. As an innovation pilot, Gushi county has carried out the chattel mortgage loan, pledge loan of enterprise management rights, mortgage loan of land management right and so on, but other counties in Xinyang are not so lucky, only 1 or 2 innovative lending is promoted and used. On the other hand, it is bad for farmers and enterprises that the existing innovative results have been used in different degrees of restrictions. Many large forest producers due to 
uncontrollable factors of forestry assets are only allowed to receive short-term small mortgage loans, it is difficult for them to expand efficiently. In fact, most of the beneficiaries of rural financial innovation products and services are concentrated in strong enterprises, the newly developed enterprises are small and weak, so it is difficult for new enterprises to solve the financial difficulties through the effective mortgage guarantee. This is also an urgent problem to be solved in financial innovation.

\section{THE MAIN REASONS OF RESTRICTING THE RURAL FINANCIAL PRODUCTS AND SERVICES INNOVATION IN HENAN PROVINCE}

\section{A. The Foundation Condition of Rural Areas Is Weak, the Economic Development Is Slow}

As a result of economic development, the finance is also the driving force of economic development. According to table 2 , since the rural financial innovation work has carried out in 2009, the rural economic development in Henan province has made amazing achievements. But due to the weak basic conditions of rural areas, there is a clear gap between the urban and the rural.

TABLE II. COMPARISON OF INCOME BETWEEN URBAN AND RURAL RESIDENTS IN HENAN PROVINCE

\begin{tabular}{|c|c|c|}
\hline Year & Disposable income of urban residents (CNY) & $\begin{array}{c}\text { Per capital net income of rural } \\
\text { residents }(\mathrm{CNY})\end{array}$ \\
\hline 2009 & 14371.56 & 4806.95 \\
\hline 2010 & 15930.26 & 5523.73 \\
\hline 2011 & 18194.80 & 6604.03 \\
\hline 2012 & 20442.62 & 7524.94 \\
\hline 2013 & 22398.03 & 8475.34 \\
\hline 2014 & 23672.00 & 9966.07 \\
\hline 2015 & 25576.00 & 10853.00 \\
\hline 2016 & 27232.92 & 11696.74 \\
\hline
\end{tabular}

a. Data Sources: statistical communique on national economic and social development of Henan

Poor infrastructure construction is the primary embodiment of weak rural basic condition. Due to the urban-rural dualistic economic structure, the financial investment of the government flows to big cities, as time goes on, the gap between the rural and urban areas is widening, the facilities construction of rural areas can't keep up with the pace of the times. Existing facilities in rural areas are characterized by small scale, poor quality and low level, for example, the village to village road has been built, but its quality is not dare to compliment, the network is not fully covered in rural areas, the condition of public service is poor, etc. Compared with the urban, the basic activities of financial institutions in rural areas are difficult to conduct, let alone financial innovation activities. Secondly, the income of farmers is low, and there is no effective collateral. The collateral of farmers includes foresty, livestocks, production equipments, land management rights and housing property rights. Foresty and livestock mortgage must be a big producer, the collateral value of production equipments is not high, the new trial of the two rights mortgage has not expanded the scope of effective collateral. Our land resources is limited, the population is too large, these leads to a limited amount of contracted land for each family. In addition, the quality of land in most regions is poor, so the amount of loan on mortgage is usually small. Similarly, the premise of housing property collateral is that there must be other long-term stable housing except mortgage housing, which is also a difficult problem for the ordinary farmers. Finally, people living in rural areas have a low cultural level, their ability to learn is limited. It is difficult for them to clarify the business processes of financial institutions and accept new products and services. This poor external business environment also restricts the enthusiasm of financial institutions for innovation. 


\section{B. The Rural Financial Structure Is Single, Financial Market Lags Behind}

At present, the structure of three industries in rural areas has been continuously rationalized and upgraded. The main body of agricultural production and management is not limited to individual farmers. Cooperatives, large producer, agricultural leading enterprises and other new business entities have been formed and have a certain scale, other industries related to agriculture are also emerging, the proportion of the second and third industry increases steadily. The country encourages people to start their own businesses and to make innovations, which expands the scale of rural entrepreneurship and develops the individual economy. At the same time, the consumption structure of rural residents is fundamentally changed, the proportion of Non-food expenditure rises year by year, and the lifestyle of farmers is becoming more and more varied. The rural economic structure of Henan province is diversified, there should be a diversified financial architecture and a highly developed financial market to adapt to it, but that's not the case.

Commercial financial institutions include banks, credit investment companies, financial firms, securities companies and so on, but there are only a variety of banks in rural areas, agricultural banks, postal savings banks, rural credit cooperatives, village banks are more common, the financial structure is very simple. With the development of finance, the disadvantages of banks to support agriculture has been exposed, agricultural banks gradually withdraw from rural areas, the business of postal savings banks is too simplex, the historical burden of rural credit cooperatives is heavy, the seniority of village banks is not enough. The single financial structure dominated by banks in a certain extent restricts the source of funds for new business entities and the transformation of agriculture and rural economy. Moreover, the demand for financial products and services in rural areas is increasing due to the diversified characteristics of rural economy, but the rural financial market still lags behind. Most of rural financial institutions still carry out the traditional "deposit, loan, remittance" business, products of insurance and finance are still blank. The service of "without leaving home" has already been conducted in urban, but it is still immature in rural areas. That is also a hindrance to financial innovation.

\section{The Concept of Financial Institutions Lags Behind, Credit Supply and Demand Is Not Balanced}

Innovation, as the main driving force of economic development, has occupied the core position of national strategy, and its key lies in the transformation and innovation of ideas. As the constructer of rural inclusive financial system, rural financial institutions should transform and upgrade the concept, and provide better services for "agriculture, rural areas and farmers". In reality, financial institutions have been aware of the importance of finance, but their business concepts is as conservative as ever. The profit of rural financial institutions still depends on deposits-loans surplus, the intermediary business income is less than 5\%, those financial institutions are basically not involved in new product $\mathrm{R} \& \mathrm{D}$. The examination and approval process of agricultural loans is complicated, the rigid credit service causes the loss of customer sources. The performance evaluation of financial institutions emphasizes scale rather than quality, managers are short-sighted, neglecting to review the long-term indicators. The service concept of insider is not enough, their differential services are based on customer identity rather than customer demand. This backward management concept has led to the lack of self-consciousness and competitiveness of financial institutions, which is bad for financial innovation.

In addition, the imbalance of rural credit supply and demand under the market mechanism also inhibits the financial innovation activities. Generally speaking, the equilibrium of credit market mainly depends on the supply and demand. Different from the urban, the rural capital demand is constrained by agricultural production, it is seasonal and cyclical. Moreover, agriculture-related loans are closely related to economic foundation and ought to have strong actual effect. But considering the uncertainty of agricultural income and the shortage of collateral, financial institutions tend not to invest in agricultural projects. With the development of rural economy, large producers continue to emerge, enthusiasm for entrepreneurship is rising, these will certainly lead to an increase in demand for credit. However, the profit-driven financial institutions usually lend the money to big projects, big enterprises and big cities, which cannot meet the demand of the rural. Meanwhile, as the major force of serving "agriculture, countryside and farmers", the loan amount of rural credit cooperatives is generally low. The micro-credit line is controlled within 30,000 yuan, and it is slightly higher with the effective collateral, but the amount will be as low as 20,000 yuan without the collateral [5]. There is also an imbalance in the loan term. The earnings time of planting industry, breeding industry, agricultural products processing industry and other industries are inconsistent, a reasonable loan period is the best choice for farmers, but the loan term of financial institutions is usually within one year. No matter the aggregate or the structure, the supply and demand of rural credit is unbalanced.

\section{Financial Supervision Evaluation Is Disadvantageous, Lacking of Relevant Supporting Policies}

The reform of rural financial system involves the reform efficiency of the whole financial system, which determines the success or failure of the financial reform. Financial supervision and evaluation mechanism as the highlight of financial reform has received much attention in recent years. "The 13th FiveYear plan" proposes to improve financial regulation, achieve the full coverage of financial risk supervision [6]. However, there are still many unfavorable factors in the rural evaluation mechanism. On one hand, the main contents of rural finance supervision are the establishment of the institution, the examination of the business and the qualification. So the backward risk monitoring and management level has caused the ratio of non-performing loans of rural commercial banks to be significantly higher than that of commercial banks. On the other hand, the internal control mechanism of rural areas has not been improved, and there is a great shortage. The unsound internal control mechanism has led to the illegal absorbing deposits and granting loans by employees, resulting in the corruption of the financial institutions and increasing the risk of financial operation. Of course, financial regulation cannot be 
separated from the power of local government and social media but the supervision of government is not in place, media supervision is not mature, so the rural financial innovation activities is restrained.

Financial innovation is a systematic project, which requires not only the improvement of financial supervision and evaluation mechanism, but also the policy support of national and local governments. Responding to the call of the state, the government has given financial discount of different degrees to rural loans, and implemented tax incentives for rural institutions. However, rural credit cooperatives and other commercial banks under the county level pay the VAT according to the standard of $3 \%$, which does not reduce the heavy burden of rural credit cooperatives. In order to activate the innovation motivation of the financial subject, this policy is obviously not enough. In addition, the innovation of rural financial products and services is also restricted by laws and regulations. Expanding the scope of collateral is a powerful way to carry out innovation activities in rural areas, it must have legal force to apply to credit markets. The issue of "agriculture, rural areas and farmers" has always been intractable, so it is impossible to complete plenty of rural tasks in a short time, which requires the national top-down legislation to ensure that innovative activities can be carried out smoothly. Lacking of supporting policies for rural finance has slowed down the pace of financial products and services innovation.

\section{E. Lacking of Rural Financial Talents and Technical Support}

Talents are the most important and scarce strategic resource of enterprises. As an iconic industy of modern society, the financial industry is in urgent need of talents. Owing to the high developing financial market of China, talents are flowing to the high-end market, which causes a shortage of talents in basic institutions. Furthermore, the rural financial innovation needs employees with strong comprehensive quality, in addition to mastering the high standard of financial and economic expertise, legal knowledge, and experimental operating skills, the staff should also be familiar with the operational law of rural economy, know about the corresponding rural policies. But in fact, the rural financial practitioners' cultural level is different, and they are not very professional. Lacking of comprehensive talents makes the research and development ability of rural finance lag far behind the urban.
Grasping talent resources is the key point to promote innovation. Of course, promoting innovation can not be separated from the support of scientific and technological means. Compared with the city, the promotion and application of technology in rural areas is seriously backward. The financial IC card that was promoted in 2011 has not been popularized in rural areas. Intelligent robot, automatic card issuing machine and other modern equipment in rural areas is still blank, the self-service electronic equipment in many towns still cannot implement the integration operation of depositing and withdrawing money. Therefore, the lack of technical support in rural areas is also the reason for restricting the innovation of financial products and services.

\section{CONCLUSION}

At present, the innovation of rural financial products and services in Henan province has achieved some results, but there are still many shortcomings. We must clearly recognize that financial innovation has never been accomplished overnight, and we should face up to and properly deal with the various bottlenecks and problems in the process of innovation. Only by making clear the main body of innovation, grasping the principle of innovation, using the correct method, providing guarantees of law, organization, policy and mechanism can rural financial innovation achieve progress by leaps and bounds and the rural economy develop better and faster [7].

\section{REFERENCES}

[1] Ming-Gui. Cao, Juan-juan Li, An Analysis of the Reasons for Restricting the Innovation of Rural Financial Products and Services in Henan Province, Journal of Xinyang Normal University ,2017(05) ,PP.43-47.

[2] Cheng. Liu, Government Report-at the 7th Session of the 12th People's Congress of Henan Province,ZhengZhou, 2017.

[3] Ying-ying.Cheng,Henan Banking Sector Loans Outstanding Balance of 1.62 Trillion Yuan at the End of June, http://finance.sina.com.cn/roll/2017-07-13/doc-ifyiakur8816164.shtml.

[4] Ge.Guo, A Number of Development Indicators of Rural Banks In our Province Are the First in the Country. Henan ;, Daily ,2017.

[5] Meng-yang.Qu,What Is the Loan Amount of Rural CreditCooperatives, https://www.rong360.com/gl/2016/10/13/116148.html.

[6] Chao.Jiang,The Financial Work Conference Hopes to Bring the Regulatory Mechanism to a Higher Level, http://money.163.com/17/0711/05/CP1SBAF2002580S6.html.

[7] Ming-Gui.Cao, Xiaohan.Jiang, The Innovation Practice and Thinking of Rural Financial Products in Henan Province, Journal of Xinyang Normal University, 2016(03), PP: 55-59. 